\title{
Manajemen Pembelajaran Guru Pendidikan Jasmani Sekolah Dasar di Kota Bima
}

\author{
Ewan Irawan ${ }^{1}$ Shutan Arie Shandi ${ }^{2}$, Salahudin ${ }^{3}$ \\ ${ }^{1}$ STKIP Taman Siswa Bima ${ }^{2}$ STKIP Taman Siswa Bima ${ }^{2}$ STKIP Taman Siswa Bima \\ 1ewanirawan23@gmail.com 2 arieshutan86@@gmail.com, ${ }^{3}$ salahudin3009@gmail.com
}

\begin{abstract}
Bima town is one of the second level regions in West Nusa Tenggara Province which consists of five districts namely Raba, East Rasanae, West Rasanae, Mpunda and Asakota districts. Through the Department of Education, and along with government programs in academic year 2014/2015 most elementary schools in the Bima town area have adopted a new curriculum, the 2013 curriculum., sports and health Primary school in the town of Bima. Data collection uses observation, interview, and documentation techniques. The data sources are taken from supervisors, principals, teachers, and students. Data validity is obtained by triangulation. Data were analyzed by (1) data reduction, (2) data presentation, and (3) drawing conclusions. The focus of this research is the management of learning carried out by physical education and physical education teachers in elementary schools in the town of Bima which includes three stages, namely (1) learning planning, (2) implementing learning, and (3) conducting evaluation.
\end{abstract}

Keywords: Learning Management of Physical, Sport, and Health Education

Abstrak. Kota Bima yang merupakan salah satu daerah tingkat II di Propinsi Nusa Tenggara Barat yang terdiri dari lima kecamatan yaitu kecamatan raba, rasanae timur, rasanae barat, mpunda dan asakota. Melalui Dinas Pendidikan, dan seiring dengan program pemerintah pada Tahun Pelajaran 2014/2015 sebagian besar SD yang ada di wilayah kota Bima telah memberlakukan kurikulum baru yaitu kurikulum 2013 Tujuan dalam penelitian ini adalah untuk mengetahui deskripsi secara langsung tentang manajemen pembelajaran yang dilaksanakan oleh guru pendidikan jasmani, olahraga dan kesehatan Sekolah dasar di Kota Bima. Pengumpulan data menggunakan teknik observasi, wawancara, dan dokumentasi.. Adapun sumber data diambil dari pengawas, kepala sekolah, guru, dan siswa. validitas data diperoleh dengan cara triangulasi. Data dianalisis dengan cara (1) reduksi data, (2) penyajian data, dan (3) penarikan simpulan. fokus penelitian ini adalah manajemen pembelajaran yang dilakukan oleh guru pendidikan jasmani olahraga dan kesehatan sekolah dasar di kota Bima yang meliputi tiga tahapan yaitu (1) perencanaan pembelajaran, (2) pelaksanaan pembelajaran, dan (3) pelaksanakan evaluasi.

\section{Kata Kunci: Manajemen Pendiakan Jasmani, Olahraga dan Kesehatan}

\section{PENDAHULUAN (12pt)}

Pendidikan jasmani, olahraga dan kesehatan merupakan bagian tidak terpisah dari pendidikan umum. Tujuannya adalah untuk membantu anak agar tumbuh dan berkembang secara wajar sesuai dengan tujuan pendidikan nasional yaitu menjadi manusia seutuhnya. Fokus perhatian pendidikan jasmani, olahraga dan kesehatan adalah peningkatan gerak, lebih khusus lagi pendidikan jasmani, olahraga dan kesehatan berkaitan dengan hubungan antara gerak manusia dan pendidikan lainnya, misalnya hubungan perkembangan fisik terhadap wilayah pertumbuhan dan perkembangan aspek lain, inilah yang menjadikan penjas unik.

Pendidikan jasmani, olahraga dan kesehatan masih dianggap sebagai pelengkap atau tempelan mata pelajaran pada kurikulum di sekolah, walaupun sebenarnya insan penjas selalu mengklaim bahwa pendidikan jasmani, olahrga dan kesehatan adalah satusatunya bidang studi yang unik, sebab pendidikan jasmani, olahraga dan kesehatan merupakan satu-satunya bidang studi yang mengurus jasmaniah namun secara langsung mengintervensi pendidikan secara 
menyeluruh. Namun masih banyak orang yang belum memahami bahwa pendidikan jasmani, olahraga dan kesehatan itu sangat potensial untuk merangsang perkembangan penalaran dan fungsi saraf yang dibutuhkan dalam pembuatan keputusan. Pengembangan pendidikan jasmani, olahraga dan kesehatan juga terkait langsung dengan pelaksanaan fungsi manajemen dalam pengertian luas yang tertuju pada pengembangan program yang mampu memenuhi kebutuhan siswa.

Kemampuan mengorganisasikan materi, metode yang diterapkan, media yang digunakan dan bagaimana cara guru melakukan sebuah inovasi pembelajaran dengan melakukan modifikasi itu menjadi solusi masalah tersebut di atas. Tetapi di samping komponen-komponen pokok yang ada di dalam kegiatan belajar mengajar, ada faktor lain yang ikut mempengaruhi keberhasilan belajar, yaitu soal hubungan antara guru dan siswa. Hubungan antara guru dan siswa/anak didik di dalam proses belajar mengajar merupakan faktor yang sangat menentukan. Bagaimanapun baiknya materi pembelajaran yang diberikan, bagaimanapun sempurnanya metode yang digunakan, namun jika hubungan antara guru dan siswa tidak harmonis maka akan dapat menciptakan suatu hasil pembelajaran yang tidak optimal atau tidak sesui dengan tujuan pembelajaran yang diharapkan. Berdasarkan beberapa fenomena di atas, maka penulis tertarik untuk meneliti bagaimanakah gambaran manajemen pembelajaran penjasorkes sekolah dasar negeri Kota Bima. Berangkat dari beberapa masalah tersebut peneliti mengangkat judul "Manajemen Pembelajaran Guru Pendidikan Jasmani, Olahraga dan kesehatan Sekolah Dasar di Kota Bima".

Manajemen diartikan dengan POAC yang tidak lain adalah pelaksanaan fungsifungsi manajemen, yakni Planning, Organizing, Actuating, and Controlling. Menurut George R Terry (2003: 9) terdapat empat fungsi manajemen, yaitu: “(1) planning (perencanaan), (2) organizing (pengorganisasian), (3) actuating (pelaksanaan), dan (4) controlling (pengawasan). George R Terry (2003: 9) manajemen meliputi: “(1) perencanaan (planning), (2) pengorganisasian (organizing), (3) penggerakan (actuating) dan (4) pengawasan (controlling).

Pendidikan jasmani sering pula diartikan dengan gerak badan, gerak fisik, gerakan jasmani, kegiatan fisik, kegiatan jasmani, bina fisik, bina jasmani. Yang pada hakikatnya berarti gerakan jasmani manusia atau dapat disebut pula gerak manusiawi (human movement). Tidak semata-mata gerak otot tapi gerak manusia seutuhnya. Gerak itu merupakan esensi. Esensi pendidikan jasmani adalah yang mengikuti batasan gerak dan waktu. Faktor esensial pendidikan jasmani adalah gerak yang mengikuti batasan waktu, ruang dan bobot. Dalam batasan waktu itulah terdapat gerakan, perubahan, pergantian, keseimbangan, keterhubungan, dan pemisahan jenis-jenis dinamika gerakan yang harus ditetapkan berdasarkan kelenturan ruang dan bobot (Rosdiani, 2013 : 66 ).

\section{METODE PENELITIAN}

Latar penelitian ini adalah bidang pendidikan dengan mendiskripsikan tentang manajemen pembelajaran yang dilaksanakan oleh guruguru penjasorkes meliputi rencana pembelajaran, pelaksanaan pembelajaran dan evaluasi pembelajaran. Penelitian ini menggunakan metode penelitian kualitatif.Sasaran penelitian ini adalah guru pendidkan jasmani, olahraga dan kesehatan, kepala sekolah, pengawas dan siswa yang ada pada sekolah dasar di Kota Bima. Informan penelitian terdiri dari: guru, kepala sekolah, pengawas dan siswa.

\section{HASIL DAN PEMBAHASAN}

Bagian ini merupakan bagian utama artikel hasil penelitian dan biasanya merupakan bagian terpanjang dari suatu artikel. Hasil penelitian yang disajikan dalam bagian ini adalah hasil "bersih". Proses analisis data seperti perhitungan statistik dan proses pengujian hipotesis tidak perlu disajikan. Hanya hasil analisis dan hasil pengujian hipotesis saja yang perlu dilaporkan beserta dengan pembahasannya. Tabel dan grafik dapat digunakan untuk memperjelas penyajian hasil penelitian secara verbal. Tabel dan grafik harus diberi komentar atau dibahas. 
Untuk penelitian kualitatif, bagian hasil memuat bagian-bagian rinci dalam bentuk sub topik-sub topik yang berkaitan langsung dengan fokus penelitian dan kategorikategori.

Pembelajaran penjasorkes dengan menggunakan perencanaan yang matang akan dapat memberikan umpan balik yang dapat menggambarkan berbagai kelemahan yang ada sehingga akan dapat menggambarkan berbagai kelemahan yang ada sehingga akan dapat meningkatkan dan memperbaiki program. Suatu pembelajaran yang memadai harus dapat menjelaskan kepada setiap orang yang terlibat, baik guru, siswa, kepala sekolah, bahkan pihak eksternal seperti orang tua dan masyarakat. Dokumen perencanaan harus dapat mengkonikasikan kepada setiap orang baik mengenai tujan dan hasil dan hasil yang hendak dicapai dan strategi yang dilakukan.

Paparan data tentang perencanaan pembelajaran yang dilakukan oleh guru penjasorkes SD Kota Bima yang diperoleh melalui wawancara dan studi dokumentasi menunjukan bahwa, pada prinsipnya guru pendidikan jasmani olahraga dan kesehatan SD Kota Bima telah membuat perencanaan pembelajaran sesuai dengan sebagian kewajiban seorang guru.

Perangkat pembelajaran yang disusun sudah disesuaikan dengan kurikulum yang berlaku, SD Kota Bima menggunakan kurikulum 2013 untuk kelas rendah sedangkan kelas tinggi masih menggunkan KTSP. Sebagian besar perangkat pembelajaran yang dibuat/disusun guru merupakan hasil dari kegitan Kelompok Kerja Guru (KKG) dan melihat contoh dari internet, namun ada juga yang merupakan hasil dari kreativitas guru.

Kegiatan kegitan Kelompok Kerja Guru (KKG) sangat membantu guru dalam menyusun perangkat pembelajaran. Namun ketika menyusun perangkat pembelajaran pada kegiatan KKG terdapat juga kendala dalam menyeragamkan perangkat pembelajaran yang harus dibuat oleh guru, masalah tersebut adalah tidak meratanya jumlah dan kualiatas sarana dan prasarana yang dimiliki oleh setiap sekolah, perangkat pembelajaran yang dibuat oleh guru haruslah disesuaikan dengan keadaan sarana dan prasarana yang dimiliki oleh sekolah. Guru cenderung langsung fotokopi perangkat pembelajaran yang dibuat dalam kegiatan $\mathrm{KKG}$, oleh karena itu guru menjadi miskin akan kreatifitas dalam merencanakan pembelajarannya padahal sebuah kreatifitas dalam merencanakan pembelajaran sangat diperlukan oleh seorang guru apalagi guru pendidikan jasmani olahraga dan kesehatan, tanpa kreatifitas maka pembelajaran akan monoton atau statis yang bisa mengakibatkan anak mudah bosan dalam mengikuti pembelajaran dan pada akhirnya hasil yang diharapkan juga tidak akan maksimal.

Paparan data di atas menggambarkan bahwa perencanaan pembelajaran yang disusun oleh guru penjasorkes SD Kota Bima relatif cukup. Pada prinsipnya guru penjasorkes SD Kota Bima telah menjalankan sebagian tugasnya yaitu membuat perencanaan pembelajaran walaupun sebagian besar perangkat pembelajaran yang dimiliki oleh guru merupakan hasil dari kegitan Kelompok Kerja Guru (KKG), hal itu menunjukkan bahwa guru penjasorkes SD Kota Bima dalam melaksanakan sebagian tugasnya yaitu melaksanakan perencanaan pembelajaran dengan membuat administrasi pembelajaran hanya formalitas saja atau menggugurkan kewajibannya untuk menjalankan sebagian tugas yang harus dilakukan oleh seorang guru.

Berdasarkan paparan data wawancara dan observasi pelaksanaan pembelajaran guru penjasorkes SD Kota Bima dapat disimpulkan secara umum sudah terlaksana dengan relatif cukup namun belum maksimal sesuai dengan perencanaan guru penjasorkes melakukan kegiatan pendahuluan yaitu berbaris, berdoa, presensi, motivasi, mempersiapkan secara psikis dan fisik dan memberi contoh secara ringkas. Guru penjasorkes memberi penjelasan secara ringkas dengan menggunakan metode demonstrasi dan ceramah.

Pada pelaksanaan pembelajaran guru penjasorkes belum bisa memaanfaatkan sumber dan media pembelajaran secara baik. 
Sumber belajar yang digunakan berupa hanya buku teks yang tersedia disekolah. Sebagian besar guru belum bisa menggunakan media penunjang seperti gambar dan vidio, untuk mengotimalkan proses dan hasil belajar siswa guru melakukan modifikasi alat karena minimnya sarana dan prasarana yang dimiliki sekolah. Hal lain yang belum maksimal dilakukan antara lain dalam mengelola kelas tidak melibatkan secara keseluruhan peserta didik, terlihat dengan adanya sebagian siswa yang hanya berdiri disamping lapangan ketika praktek materi permainan dan olahraga. selama observasi berlangsung dalam kegiatan akhir Guru tidak menyimpulkan dan memberi umpan balik kepada peserta didik. terbukti setelah melakukan praktek, peserta didik langsung dibubarkan tanpa ada penjelasan oleh Guru. Begitupun keterangan dari hasil wawancara informan siswa mengemukakan bahwa tidak pernah melakukan pendinginan atau pelemasan karena setelah olahraga langsung istirahat.

Paparan data pelaksanaan evaluasi pembelajaran yang dilakukan oleh guru penjasorkes SD Kota Bima menggambarkan bahwa guru penjasorkes SD Kota Bima sudah melakukan evaluasi pembelajaran dengan baik. Evaluasi berjalan sesuai dengan apa yang direncanakan. Sebagian besar Guru penjasorkes SD Negeri Kota Bima melaksanakan evaluasi setiap kali pertemuan dan selesai melaksanakan satu kompetensi dasar. Pelaksanaan evaluasi yang dilaksanakan oleh guru bervariatif ada yang melaksanakan evaluasi proses, ada yang melaksanakan evaluasi hasil, tetapi ada juga guru yang melaksanakan kedua-duanya tergantung dari kompetensi dasar yang dipelajari. Guru penjasorkes SD Kota Bima tidak hanya sebatas melakukan evaluasi namun ada tindak lanjut dari hasil evaluasi tersebut dengan melakukan program remedial dan pengayaan jika masih ada siswa yang belum tuntas, sebagian guru memberikan program remedial sebelum pindak ke kompetensi dasar lain, sebagian memberikan program remedial dan pengayaan pada akhir semester ada juga yang memberikan program tersebut pada kegiatan ekstra kurikuler.

\section{KESIMPULAN}

Setelah dilakukan pembahasan terhadap data yang diperoleh selama pelaksanaan penelitian, maka dapat diperoleh suatu gambaran tentang pelaksanaan manajemen pembelajaran guru penjasorkes pada sekolah dasar di Kota Bima sebagai berikut:

Pertama, guru penjasorkes SD di Kota Bima pada prinsipnya telah membuat perencanaan pembelajaran. Namun, perencanaan pembelajaran berupa perangkat pembelajaran yang dimiliki oleh guru sebagian besar merupakan hasil dari kegitan kelompok kerja guru (KKG), melihat contoh dari internet dan ada juga hasil kreatifitas guru itu sendiri.

Kedua, guru penjasorkes SD di Kota Bima, telah melaksanakan pembelajaran dengan relatif cukup. Namun belum maksimal sesuai dengan perencanaan, guru penjasorkes melakukan kegiatan pendahuluan yaitu berbaris, berdoa, presensi, motivasi, mempersiapkan secara psikis dan fisik dan memberi contoh secara ringkas. Guru penjasorkes memberi penjelasan secara ringkas dengan menggunakan metode demonstrasi dan ceramah.

Pada pelaksanaan pembelajaran guru penjasorkes belum bisa memaanfaatkan sumber dan media pembelajaran secara baik. Sumber belajar yang digunakan berupa hanya buku teks yang tersedia disekolah. Sebagian besar guru belum bisa menggunakan media penunjang seperti gambar dan vidio, untuk mengotimalkan proses dan hasil belajar siswa guru melakukan modifikasi alat karena minimnya sarana dan prasarana yang dimiliki sekolah. Hal lain yang belum maksimal dilakukan antara lain dalam mengelola kelas tidak melibatkan secara keseluruhan peserta didik, terlihat dengan adanya sebagian siswa yang hanya berdiri disamping lapangan ketika praktek materi permainan dan olahraga. selama observasi berlangsung dalam kegiatan akhir guru tidak menyimpulkan dan memberi umpan balik kepada peserta didik. terbukti setelah 
melakukan praktek, peserta didik langsung dibubarkan tanpa ada penjelasan oleh guru.

Ketiga, pada prinsipnya guru penjasorkes SD Kota di Bima sudah melakukan evaluasi. Evaluasi yang dilakukan oleh guru penjasorkes SD di Kota Bima adalah setiap kali selesai mempelajari satu kompetensi dasar kemudian melaksanakan evaluasi. Dalam melaksanakan evaluasinya bervariatif ada yang menggunakan evaluasi proses, ada yang menggunakan evaluasi hasil, serta ada juga yang menggunakan kedua-duanya yaitu evaluasi hasil dan evaluasi proses. Guru penjasorkes sekolah dasar di Kota Bima tidak sebatas melakukan evaluasi saja namun guru juga memberikan tindak lanjut dari hasil evaluasi, guru memberikan program remedial dan pengayaan jika masih terdapat siswa yang belum tuntas sesui dengan standar KKM yang telah ditentukan pada perencanaan pembelajaran.

SARAN

Berdasarkan hasil penelitian dan kenyataan yang ada di lapangan, maka peneliti dapat memberikan saran sebagai berikut:

1. Dinas Pendidikan pemuda dan olahraga maupun Kegitan kelompok kerja guru (KKG) hendaknya sesering mungkin membuka kerja sama dengan lembagalembaga pendidikan di luar Kota Bima guna menambah pengetahuan serta kemampuan guru dalam melaksanakan tugasnya, seperti mengadakan workshop, penataran, maupun istilah lain yang tujuannya tidak lain mengasah kemampuan guru dalam menenej pembelajarannya, sehingga lambat laun manajemen pembelajaran yang dilakukan guru makin lama akan makin meningkat.

2. Pengawas dan kepala sekolah hendaklah sesering mungkin mengadakan supervisi kinerja guru dari membuat perencanaan, pelaksanaan pembelajaran, melaksanakan evaluasi, dan melaksanakan tindaklanjut hasil evaluasi yang dilakukan guru di sekolah, kalau perlu supervisi tersebut dilaksanakan secara terus menerus dan berkelanjutan, serta hasil dari supervisi yang dilakukan oleh kepala sekolah digunakan sebagai dasar penilaian kinerja guru dalam menjalankan tugasnya.

3. Kepala sekolah selaku manajer dan penanggungjawab seluruh pelaksanaan kegiatan pembelajaran di sekolah, perlu mewajibkan kepada semua guru dalam membuat perencanaan pembelajaran hanya ditulis dengan tangan, sehingga akan memperkecil kemungkinan para guru melakukan fotokopi buatan orang lain.

4. Guru penjasorkes sebagai pengelola dan pelaksana manajemen pembelajaran hendaknya: (a) Inovatif dan kreatif dalam merencanakan pembelajaran dengan tetap berpedoman pada kebutuhan dan kemampuan siswa serta keadaan sarana prasarana yang dimiliki oleh sekolah, sehingga dalam merencanakan pembelajaranya tidak selalu menngacu pada hasil kegitan kelompok kerja guru (KKG). (b) menyesuaikan materi pembelajaran dengan perencanaan, urutan dan langkah-langkah pembelajaran serta mampu melakukan kombinasi dari berbagai metode mengajar serta melakukan modifikasi mengajar jika diperlukan. (c) melakukan evaluasi pembelajaran secara berkesinambungan, sehingga dari evaluasi tersebut dapat dijadikan oleh guru sebagai refleksi atau renungan untuk merubah dan memperbaiki strategi pembelajaran.

5. Guna merangsang kinerja guru penjasorkes dalam melaksanakan tugasnya, dipandang perlu sekolah dan dinas pendidikan memberikan penghargaan (reward) bagi para guru yang mempunyai kinerja baik dalam mengelola pembelajarannya.

\section{UCAPAN TERIMA KASIH}

Ucapan terima kasih dan penghargaan yang sebesar-besarnya penulis sampaikan kepada bapak Dr. Ibnu Khaldun Sudirman, M.Si. selaku ketua lembaga STKIP Taman Siswa Bima serta teman-teman dosen yang telah memberikan dukungan dan motivasi sehingga terlaksananya penelitian ini.

Ucapan terima kasih yang tak terhingga kepada tim peneliti bapak Shutan Arie Shandi, M.Pd dan bapak Salahudin, M.Pd.i 
yang ikut membantu dalam pelaksanaan penelitian ini sehingga berjalan dengan lancar.

Ucapan terimakasih pula kami sampaikan kepada Pengawas, Kepala Sekolah serta guru-guru Penjasorkes SD sekota Bima yang ikut memberikan kontribusi sehingga terlaksana kegiatan penelitian ini dengan baik.

\section{DAFTAR PUSTAKA}

Hamalik. (2013). Proses Belajar Mengajar. Jakarta : Bumi Aksara

Husdarta, (2011). Manajemen Pendidikan Jasmani. Bandung : Alfabeta

Ihsan dan Hasmiyati, (2011). Manajemen Pendidikan Jasmani Olahraga dan Kesehatan. Makassar : Penerbit UNM.

Moleong, (2014). Metode Penelitian Kualitatif. . Bandung: PT Remaja Rosdakarya

Nasution dan Suryanto, (2007). Evaluasi Pengajaran. Jakarta: Universitas Terbuka.

Paturusi, (2012). Manajemen Pendidikan Jasmani dan Olahraga. Jakarta: Rineka Cipta.

Peraturan Menteri Pendidikan dan Kebudayaan Republik Indonesia Nomor 65 Tahun 2013Tentang Standar Proses Pendidikan Dasar dan Menengah

Peraturan Menteri Pendidikan Nasioanal No. 22 tahun (2006). Jakarta: PT Binatama Raya.

Rosdiani, (2012). Model Pembelajaran Langsung dalam Pendidikan Jasmani dan Kesehatan. Bandung : Alfabeta. 